\title{
Abiotic and biotic controls on the copepod Pseudodiaptomus forbesi in the upper San Francisco Estuary
}

\author{
Karen Kayfetz ${ }^{1, *}$, Wim Kimmerer ${ }^{2}$ \\ ${ }^{1}$ Delta Science Program, Delta Stewardship Council, 980 9th St, Sacramento, CA 95814, USA \\ ${ }^{2}$ Romberg Tiburon Center for Environmental Studies, San Francisco State University, 3152 Paradise Drive, Tiburon, \\ CA 94920, USA
}

\begin{abstract}
Salinity is a key control on species distribution in estuaries, but interspecific interactions can shift distributions of estuarine species away from physiologically optimal salinities. The distribution of the introduced calanoid copepod Pseudodiaptomus forbesi in the upper San Francisco Estuary (SFE) shifted from brackish to fresh water in 1993 following the introductions of 2 brackish-water copepods, the small but numerically dominant Limnoithona tetraspina (Cyclopoida) and the predatory Acartiella sinensis (Calanoida). The nearly simultaneous timing of these introductions complicated interpretation of the temporal change in distribution of $P$. forbesi. Although $P$. forbesi is now uncommon at salinity $>\sim 2$, which might be interpreted as the result of salinity stress, short-term experiments showed high survival of adults up to salinity $\sim 8$ and of nauplii to salinity of at least 14 , and reproduction was highest at salinity 5 . Feeding experiments showed some overlap in diets of $P$. forbesi and $L$. tetraspina, but $P$. forbesi consumed a broader range of prey than $L$. tetraspina. Furthermore, feeding rates of the $L$. tetraspina population appeared insufficient to reduce prey availability to $P$. forbesi. Previous reports of high consumption of nauplii by A. sinensis and the clam Potamocorbula amurensis suggest that these interspecific interactions are important in constraining the distribution of $P$. forbesi in the upper SFE. Thus, we interpret the temporal shift in distribution of $P$. forbesi as due mainly to the introduction of the predatory copepod, whose high abundance may have been facilitated by the availability of a common alternative prey, L. tetraspina.
\end{abstract}

KEY WORDS: Competition - Distribution - Facilitation · Low-salinity zone · Food web · Limnoithona tetraspina $\cdot$ Salinity tolerance

\section{INTRODUCTION}

Salinity is the main physical control on species distributions in estuaries. Many estuarine species are abundant only within a limited range of salinity (Jeffries 1962, Bulger et al. 1993), and salinity tolerance is traditionally considered to be the determining factor in the distributions of pelagic species (Soetaert \& Van Rijswijk 1993, Telesh \& Khlebovich 2010). Although the effects of salinity through tolerance of a species may seem obvious, they may obscure the

\footnotetext{
${ }^{*}$ Corresponding author: karen.kayfetz@deltacouncil.ca.gov
}

importance of interspecific interactions. Food availability and the distribution of predators and competitors often covary with salinity, and exert bottom-up and top-town controls on a species. These other factors may be more important determinants of habitat suitability than salinity alone (Rippingale \& Hodgkin 1975, Maciej Gliwicz 2002, Cloern \& Dufford 2005).

Zooplankton play a key role in pelagic food webs, transferring energy from phytoplankton and microbes to higher trophic levels (Runge 1988). Few studies have examined how interspecific interactions shape

() The authors 2017. Open Access under Creative Commons by Attribution Licence. Use, distribution and reproduction are unrestricted. Authors and original publication must be credited. 
zooplankton distribution in the field, and the available literature is almost entirely from lakes (DeMott 1989, Urabe 1990, Shurin et al. 2001). In open systems such as estuaries, it is difficult to infer interspecific interactions from field data, except when perturbations cause changes in species composition. Such cases occur when new species are introduced. Species introductions act as natural experiments, wherein the niche occupied by native or naturalized species may be studied before and after an introduction. Ecosystem changes resulting from species introductions may be reflected in changes to the distribution or abundance of native or naturalized species (Alpine \& Cloern 1992, Shiganova 1998, Kimmerer 2006, Lehtiniemi \& Gorokhova 2008).

The San Francisco Estuary (SFE) is a highly invaded ecosystem (Cohen \& Carlton 1998, Orsi \& Ohtsuka 1999). Frequent introductions in this system have been associated with substantial changes in abundance and species composition of the native and naturalized species. Invasive species have altered productivity and food web efficiency (Alpine \& Cloern 1992, Kimmerer et al. 1994, Greene et al. 2011, Kimmerer \& Thompson 2014) and have been linked to declines in native fish populations (Bennett \& Moyle 1996, Sommer et al. 2007).

The invasion of the clam Potamocorbula amurensis in 1986 into the SFE had particularly notable effects on the lower food web (Carlton et al. 1990). Grazing by this clam has been implicated in eliminating summertime phytoplankton blooms (Alpine \& Cloern 1992) and in declines of primary consumers (Kimmerer et al. 1994, Kimmerer \& Orsi 1996, Kimmerer \& Lougee 2015). By consuming a large proportion of the phytoplankton and microzooplankton production in the system, $P$. amurensis competes with suspension-feeding zooplankton (Greene et al. 2011, Kimmerer \& Thompson 2014), and the clam also directly consumes copepod nauplii (Kimmerer \& Lougee 2015).

The copepod fauna of the upper SFE consists of a small number of species, mostly introduced from East Asia (Orsi \& Ohtsuka 1999). The copepod Pseudodiaptomus forbesi, first reported in the upper SFE in 1987, probably arrived in ballast water from its native waters in China (Orsi \& Walter 1991). Since 1989, it has been the most abundant calanoid copepod in the upper SFE from spring through autumn and is an important food source for larval and juvenile fish, including the endangered delta smelt Hypomesus transpacificus (Nobriga 2002, Hobbs et al. 2006, Slater \& Baxter 2014). Three additional copepod species were introduced from East Asia in 1993, 2 of which established populations in brackish waters of the upper SFE: the small cyclopoid Limnoithona tetraspina and the predatory calanoid Acartiella sinensis (Orsi \& Ohtsuka 1999). Shortly after its introduction, $L$. tetraspina became the most numerically abundant copepod in the upper SFE (Bouley \& Kimmerer 2006).

Historical records from long-term zooplankton monitoring (Orsi \& Mecum 1986) indicate a shift in the distribution of $P$. forbesi to a lower salinity around 1993 (Kimmerer et al. 1998, Slaughter et al. 2016). This shift in distribution did not co-occur with any long-term changes in hydrology (Cloern \& Jassby 2012), but it was concurrent with the introduction of the 2 new brackish-water copepod species (Orsi \& Ohtsuka 1999). Thus, we hypothesized that these introduced copepod species may have altered the distribution of $P$. forbesi through predation or by competition for a limited food supply. Alternative explanations for the shift of $P$. forbesi to lower salinity include a change in salinity tolerance or an increase in food availability which could provide the energy necessary to tolerate fresh water, both of which have been observed in the species complex Eurytemora affinis (Lee 1999, Lee et al. 2013).

The aim of this study was to investigate controls on the distribution of $P$. forbesi in the upper SFE, including salinity tolerance and potential interspecific interactions with $L$. tetraspina. A sister study investigated predation by $A$. sinensis on $P$. forbesi and $L$. tetraspina (Slaughter et al. 2016). The results of these studies together help us narrow the possible explanations for the upstream shift in distribution of $P$. forbesi. We conducted 3 sets of experiments for this study (1) to determine the effects of salinity on survival and reproduction of $P$. forbesi, (2) to assess the potential for competition for food between $P$. forbesi and $L$. tetraspina by determining feeding rates on natural prey, and (3) to assess the potential for predation of $L$. tetraspina on $P$. forbesi nauplii. To further evaluate potential causes of the upstream shift, we calculated predation mortality to the $P$. forbesi population due to $P$. amurensis and $A$. sinensis.

\section{MATERIALS AND METHODS}

\section{Study area}

The upper SFE includes the brackish-water region of Suisun Bay and Marsh and the largely freshwater delta of the Sacramento and San Joaquin Rivers. This region is strongly tidally influenced and vertically 
well-mixed and is characterized by high nutrients, high turbidity, and low productivity (Jassby \& Cloern 2000, Kimmerer et al. 2012).

We define the low-salinity zone (LSZ) as the region of the estuary with salinity of $\sim 0.5-5$ (practical salinity scale), essentially the oligohaline zone of the Venice classification system. The position of the LSZ has been used as a tool for managing freshwater outflow and diversions, and as a habitat index for several pelagic species (Jassby et al. 1995, Kimmerer 2004). This region encompasses most of the summerautumn habitat for the endangered, endemic delta smelt (Bennett 2005).

\section{Monitoring data}

We obtained historical abundance data for Pseudodiaptomus forbesi and Limnoithona spp. from the Interagency Ecological Program (IEP) zooplankton monitoring survey (www.water.ca.gov/bdma/meta/ zooplankton.cfm). Temperature and conductivity were measured at every station (Orsi \& Mecum 1986) and conductivity was converted to salinity (practical salinity scale).

Two species of Limnoithona occur in the estuary, but adults have been routinely identified to species in the monitoring data only since 2007. L. tetraspina dominates its congener by at least an order of magnitude, and is most abundant in the LSZ compared to L. sinensis, which is primarily found in fresh water (Bouley \& Kimmerer 2006). Therefore, we treated counts of Limnoithona spp. from the LSZ before 2007 as L. tetraspina for our calculations. Nauplii of Limnoithona are not reliably identifiable in mixed samples, as their morphology has not been described (Fofonoff et al. 2017), so we used counts of unidentified nauplii as a proxy for $L$. tetraspina nauplii. This is a close approximation because during springautumn, L. tetraspina is 1 to 2 orders of magnitude more abundant than any other copepod species in the LSZ, and the nauplii of every other abundant copepod are identified to species.

The shift in distribution of $P$. forbesi was quantified using abundance data from June-October 19892016. The annual median abundance in fresh water (salinity, $\mathrm{S}<0.5$ ) was calculated, and the seaward limit of the distribution was calculated for each year as the maximum salinity at which abundance was at least as great as 10,25 , or $100 \%$ of the freshwater median. The time series of each of these values was analyzed to identify a single change point using the changepoint package in R (Killick \& Eckley 2014).
The means and confidence intervals of the pre- and post-change data were then determined. This method removes the effect of uneven sampling in salinity space, which would bias estimates based on presence or absence in the samples.

During 1994, the zooplankton monitoring program was reduced to about $40 \%$ of its previous level of sampling effort. Stations were removed from the program or replaced with nearby stations, stations were added, and sampling effort decreased from twice to once monthly. Because these changes coincided in time with the change of interest, it was essential to take the changes in monitoring into account when analyzing the data. We used 4 different versions of the dataset to ensure the analysis was robust, progressively eliminating stations to try to minimize bias due to changing sampling effort. Below, we present results of analysis with ca. half of the stations removed and 1 of each pair of surveys in each month before 1994 selected at random (Dataset 2), which reduced the total number of samples from 3958 to 2373 with between 73 and 98 samples $\mathrm{yr}^{-1}$. Results using the full data set or other reductions were similar (see the Supplement at www.int-res.com/articles/ suppl/m581p085_supp.pdf).

\section{Sampling and laboratory conditions}

Laboratory studies were conducted in the summer and autumn when freshwater inputs are low, water temperatures are high $\left(\sim 18-22^{\circ} \mathrm{C}_{i}\right.$ Kimmerer 2004), and $P$. forbesi is abundant. Copepods and surface water for experiments were collected at several stations in the upper estuary (Table 1). Temperature and salinity were measured in situ with a handheld meter (YSI Model 30). Copepods were collected by a gentle subsurface tow of a $150 \mu \mathrm{m}$ mesh, $0.5 \mathrm{~m}$ diameter plankton net equipped with a non-filtering plastic cod end to minimize damage to organisms. Tow contents were diluted in 201 insulated coolers of surface water for transport back to the Romberg Tiburon Center $\left(37.889^{\circ} \mathrm{N}, 122.447^{\circ} \mathrm{W}\right)$, where all experiments were conducted. Additional surface water for experiments was collected with a clean bucket and transported in insulated coolers.

All experiments and acclimations were conducted in a temperature-controlled room maintained at $19^{\circ} \mathrm{C}$ on a 14:10 h light:dark cycle, which approximately mimics the summer conditions in this estuary. Field water used in experiments was filtered by siphoning through a submerged mesh screen affixed to a PVC pipe to remove particles larger than the specified 
Table 1. Field and laboratory conditions for experiments. Copepods were collected at 4 stations in the Upper Estuary: Martinez Pier in the low-salinity zone, Antioch at the confluence of the 2 rivers, Rio Vista in the Sacramento River, and Twitchell Island in the San Joaquin River. Field and laboratory salinity (Sal, practical salinity scale) and temperature $\left(\mathrm{Temp},{ }^{\circ} \mathrm{C}\right)$, number of copepods per replicate (N), number of replicates (Reps) per treatment, incubator volume ( $\mathrm{Vol}, \mathrm{ml}$ ), and mode of analysis on FlowCAM for grazing experiments. Dates are given as mm.dd.yy

\begin{tabular}{|c|c|c|c|c|c|c|c|c|c|c|c|c|c|}
\hline Expt & Date & Sample site & Lat $\left({ }^{\circ} \mathrm{N}\right)$ & Long $\left({ }^{\circ} \mathrm{W}\right)$ & Species & \multicolumn{2}{|c|}{ Field } & \multicolumn{2}{|c|}{ Laboratory } & $\mathrm{N}$ & Reps & Vol & $\begin{array}{l}\text { FlowCAM } \\
\text { mode }\end{array}$ \\
\hline \multicolumn{14}{|c|}{ Acute salinity tolerance } \\
\hline & 06.20 .12 & Antioch & 38.021 & 121.820 & $\begin{array}{l}\text { Pseudodiaptomus } \\
\text { forbesi }\end{array}$ & 0.7 & 21.4 & $0-16$ & 19 & 10 & 3 & 15 & - \\
\hline \multicolumn{14}{|c|}{ Effects of salinity on reproduction } \\
\hline & 05.21 .13 & Rio Vista & 38.159 & 121.687 & P. forbesi & 0.1 & 20.4 & $0-12$ & 19 & 1 & $24-29$ & 15 & - \\
\hline \multicolumn{14}{|c|}{ Grazing experiments } \\
\hline 1 & 08.30 .11 & Antioch & 38.021 & 121.820 & P. forbesi & 0.4 & 21.3 & 0.4 & 19 & 6 & 4 & 175 & Fluorescence \\
\hline \multirow[t]{2}{*}{2} & 09.07 .11 & Antioch & 38.021 & 121.820 & P. forbesi & 0.1 & 21.4 & 0.1 & 19 & 6 & 4 & 175 & Fluorescence \\
\hline & 09.07 .11 & Martinez Pier & 38.028 & 122.139 & $\begin{array}{l}\text { Limnoithona } \\
\text { tetraspina }\end{array}$ & 7.4 & 20.5 & 0.1 & 19 & 50 & 4 & 175 & Fluorescence \\
\hline \multirow[t]{2}{*}{3} & 09.13 .11 & Antioch & 38.021 & 121.820 & P. forbesi & 0.1 & 20.5 & 0.1 & 19 & 6 & 4 & 175 & Fluorescence \\
\hline & 09.13 .11 & Martinez Pier & 38.028 & 122.139 & L. tetraspina & 6.6 & 19.8 & 0.1 & 19 & 50 & 4 & 175 & Fluorescence \\
\hline 4 & 09.27 .11 & Rio Vista & 38.159 & 121.687 & P. forbesi & 0.1 & 20.0 & 0.1 & 19 & 6 & 4 & 175 & Auto-image \\
\hline 5 & 10.04 .11 & Twitchell Is. & 38.095 & 121.668 & P. forbesi & 0.1 & 18.4 & 0.1 & 19 & 6 & 4 & 175 & Auto-image \\
\hline 6 & 10.04 .11 & Antioch & 38.021 & 121.820 & P. forbesi & 0.3 & 20.0 & 0.3 & 19 & 6 & 4 & 175 & Auto-image \\
\hline \multicolumn{14}{|c|}{ Predation by $L$. tetraspina on $P$. forbesi } \\
\hline & atumn 2012 & Laboratory cul & cures & & $0.1-1.1$ & & 2 & 19 & 20 & 7 & 15 & - & \\
\hline
\end{tabular}

mesh size, or by vacuum pump through a $47 \mathrm{~mm}$ Whatman GF/F filter (effective pore size $0.7 \mu \mathrm{m}$ ) to remove all particles.

\section{Acute salinity tolerance}

Acute salinity tolerance (salinity shock) experiments were conducted with copepods collected in late June 2012 from Antioch ( $\mathrm{S}=0.7$; Table 1). Within $4 \mathrm{~h}$ of collection, adult female $P$. forbesi (both ovigerous and non-ovigerous) were sorted from the tow contents under a dissecting microscope and trans- ferred to a 41 plastic beaker containing GF/F-filtered water from the collection site. Copepods were given $48 \mathrm{~h}$ to acclimate to laboratory conditions before being sorted into treatments. During this time, copepods were gently aerated and fed once daily in excess (>500 $\mu \mathrm{g} \mathrm{C}^{-1}$ ) a diet (Table 2) based on past experience culturing $P$. forbesi (Sullivan \& Kimmerer 2013).

After the acclimation period, adults were filtered onto a $200 \mu \mathrm{m}$ mesh sieve, and the filtrate, containing nauplii that had hatched during the $48 \mathrm{~h}$ acclimation, was concentrated on a $53 \mu \mathrm{m}$ mesh. Copepods were washed from the sieves into petri dishes with GF/F-

Table 2. Live algal cultures and cryopreserved algae fed to Pseudodiaptomus forbesi in salinity-tolerance experiments. Details on culture media are provided in the 'Materials and methods'

\begin{tabular}{|llll|}
\hline Experiment & Treatment & \multicolumn{1}{c|}{ Cultured or cryopreserved food and supplier } \\
\hline Acute salinity tolerance & Prior to experiment & Selenastrum capricornutum & UTEX 1648 \\
& & Chlamydomonas reinhardtii & UTEX 90 \\
& & Scenedesmus obliquus & Reed Mariculture \\
& & Shellfish Diet ${ }^{\circledR}$ & Reed Mariculture \\
Effects of salinity on reproduction & All treatments & Nannochloropsis & UTEX 1648 \\
& & Selenastrum capricornutum & UTEX LB FD257 \\
& & Cyclotella meneghiniana & Reed Mariculture \\
& & Shellfish Diet ${ }^{\circledR}$ & Reed Mariculture \\
& & Nannochloropsis & UTEX LB 35 \\
& Salinities 0.1,2,5 & Cryptomonas ovata & CCMP 1419 \\
& Salinities 8, 12 & Rhodomonas salina & \\
& & & \\
& & &
\end{tabular}


filtered water from the collection site. Non-ovigerous adult female $P$. forbesi were sorted under a dissecting microscope into 30 groups of 10 individuals, and each group was kept in a $5 \mathrm{ml}$ holding well. Only females were used because tolerance to salinity shock may differ between sexes (Roddie et al. 1984). Nauplii were sorted as described for adults. Once all copepods had been sorted, they were transferred by pipette into glass vials containing $15 \mathrm{ml}$ of water at 10 treatment salinities: $0,0.7,2,4,6,8,10,12,14$, and 16. Each treatment was replicated 3 times with adults and 3 times with nauplii. The 0 salinity treatment was deionized water, and the 0.7 salinity treatment was GF/F-filtered water from the field collection site. The other treatments were prepared by mixing GF/Ffiltered water from the collection site with GF/Ffiltered water collected from Central San Francisco Bay $(\mathrm{S}=26)$.

Copepods were incubated for $48 \mathrm{~h}$, during which time they were not fed. At the end of the $48 \mathrm{~h}$, copepods were stained with the vital stain Neutral Red (dimethyl diaminophenazine chloride). To each vial we added $0.15 \mathrm{ml}$ of a $0.1 \%$ solution (for a final concentration of 1:100 000), allowed the copepods $20 \mathrm{~min}$ to take up the stain, then killed and preserved them in a $4 \%$ formaldehyde solution (Fleming \& Coughlan 1978). Copepods were later counted under a dissecting microscope and identified as having survived or not survived the treatment, based on uptake of the vital stain (Dressel et al. 1972). To calculate survival rates by salinity, we fit a generalized linear model with a binomial error distribution to the count data using the function 'glm' from the 'stats' package in the R statistical computing environment version 3.0.1 (R Development Core Team 2013).

\section{Effects of salinity on reproduction}

Experiments testing the effects of salinity on reproduction were conducted from May to June of 2013 with copepods collected from Rio Vista $(\mathrm{S}=0.1$; Table 1). Within $2 \mathrm{~h}$ of collection, copepods were transported to the laboratory and an artificial cohort of juveniles (sensu Kimmerer \& McKinnon 1987) was filtered out of the tow contents using 150 and $175 \mu \mathrm{m}$ mesh sieves. The resulting cohort was composed of late nauplii (mostly NVI) and early copepodites (CI and CII). These copepods were distributed among 10 culture buckets containing GF/F-filtered water from the collection site. Copepods were acclimated gradually from salinity 0.1 to salinities $2,5,8$, and 12 over 5 d. Duplicate cultures were maintained at each sa- linity treatment. Salinity in the cultures was increased stepwise, once a day, by adding GF/F-filtered seawater $(\mathrm{S}=32)$ until the new target salinity was reached as determined with a handheld meter (YSI Model 30). This rate of acclimation is conservative compared to that used by others in copepod salinity tolerance experiments (Lee \& Petersen 2003, Chen et al. 2006). After the final salinity was reached, copepods were left for $3 \mathrm{~d}$ while they matured to adults.

Cultures were maintained as in the acute salinitytolerance experiments except for the live algae species that they were fed (Table 2). Inoculate cultures of algal species were grown in fresh water (WC Medium), salinity 5 , and salinity 10 media (WC Medium spiked with filtered and sterilized sea water) to prevent any effect on quality or vitality of algal food because of salinity shock. Copepods at salinities 8 and 12 were fed Rhodomonas salina instead of Cryptomonas ovata because $C$. ovata could not be successfully acclimated up to salinity 10 culture media and $R$. salina could not be acclimated to grow in fresh water.

Five days after cultures were established, 12-15 ovigerous females were removed from each duplicate culture and placed individually in $15 \mathrm{ml}$ wells in flat-bottom tissue-culture well plates. These females continued to be fed daily with the same diet they received in the culture buckets. Plates were checked twice daily and hatched nauplii were counted. Observations of naupliar condition were recorded, i.e. how many nauplii were actively swimming and how many appeared dead or had failed to hatch with the rest of the clutch. Some females dropped their egg sacs before the eggs were fully developed and no nauplii hatched from those abandoned egg sacs; these clutches ( 3 of the 125 clutches observed) were not included in the analysis. For each treatment, mean clutch sizes were calculated with $95 \%$ confidence intervals.

\section{Feeding by $P$. forbesi and $L$. tetraspina}

Six grazing experiments were conducted with $P$. forbesi in the fall of 2011; 2 experiments also included L. tetraspina (Table 1). For the 2 experiments that included $L$. tetraspina, copepods were collected from 2 different locations, one where $P$. forbesi was the dominant species (Antioch) and the other where L. tetraspina was the dominant species (Martinez Pier), to facilitate sorting in the laboratory. Tow contents from Martinez Pier were transferred into water from Antioch for 3-4 h before copepods were sorted, to allow for acclimation of copepods to the experi- 
mental conditions; both copepod species were incubated in water from Antioch for the experiments (Table 1) so that initial prey concentrations would be the same for both copepod species.

Surface water from the field was gently screened with a $100 \mu \mathrm{m}$ mesh filter into a clean 201 bucket to remove larger grazers as previously described. The screened water was then stirred gently to homogenize contents and siphoned into $175 \mathrm{ml}$ incubation bottles. Adult female copepods were sorted into holding vessels containing GF/F-filtered field water (with no food) where they remained for 90-120 min before being added to incubation bottles. Bottles were covered with parafilm and tightly capped to prevent the formation of air bubbles, which can damage fragile protists (Gifford 1993). Once capped, bottles were mounted on a plankton wheel rotating at 1-2 rpm in a temperature-controlled room at $19^{\circ} \mathrm{C}$ on a 14:10 h light:dark cycle. For each experiment we used 4 initial bottles, 4 controls with no grazers, and 4 experimental bottles for each copepod species.

After 15 min on the plankton wheel, the initial bottles were collected for analysis. This time allows the plankton assemblage to adjust to effects of handling, as most losses due to handling occur immediately (Gifford 1993). Experimental bottles and final controls were incubated for $24 \mathrm{~h}$. From each bottle, a 25-50 ml sample of filtrate was transferred to a $50 \mathrm{ml}$ plastic centrifuge tube and preserved by adding acid Lugol's solution to a final concentration of $\sim 1 \%$. These samples were settled using the Utermöhl method (Sherr \& Sherr 1993), and cells were counted at a later date on a Wild M40 inverted microscope at $100 \times$ magnification. Additional samples were collected for immediate analysis using a FlowCAM (Fluid Imaging Technologies) imaging flow cytometer.

The FlowCAM uses a syringe pump to move fluid through a narrow glass flow chamber at a controlled rate (Sieracki et al. 1998). A section of the flow chamber is oriented in front of a microscope objective and digital camera; as cells pass through the chamber, digital images are captured and stored in a database. In fluorescence-trigger mode, a laser that stimulates chlorophyll a autofluorescence is active. When a particle passing through the flow chamber fluoresces, a detector triggers the camera and the contents of the flow chamber are imaged (Sieracki et al. 1998). In auto-image mode, images are captured at consistent, user-defined intervals up to 20 images $\mathrm{s}^{-1}$. Visual Spreadsheet software version 9.0 (Fluid Imaging Technologies) automatically measures particle size and other characteristics based on the image and stores these data along with the particle images. In post-processing, these characteristics can be used to automate sorting and classification of particles.

In Expts 1-3, the fluorescence-trigger mode was used to analyze live samples (Table 1). Bottles were stored in a dark refrigerator at $4^{\circ} \mathrm{C}$ for a maximum of $2 \mathrm{~h}$ to minimize growth and grazer activity during processing (Liu et al. 2005, Ide et al. 2008). Bottles were gently inverted at least 50 times before $1.5 \mathrm{ml}$ subsamples were taken by pipette and processed through the FlowCAM.

In Expts 4-6, the auto-image mode with a frame rate of 20 images $\mathrm{s}^{-1}$ was used to analyze preserved samples (Table 1). The bottles of filtrate were preserved in $4 \%$ glutaraldehyde and stored in a dark refrigerator at $4{ }^{\circ} \mathrm{C}$ for a maximum of $48 \mathrm{~h}$. Bottles were inverted at least 50 times before $5 \mathrm{ml}$ subsamples were transferred by pipette to be processed through the instrument, which imaged $0.94 \mathrm{ml}$ of the sample.

\section{Analysis of feeding experiments}

Images stored in the FlowCAM database were sorted in the Visual Spreadsheet software and classified into broad taxonomic categories based on visual identification of the cell images. Sample volumes analyzed on the FlowCAM were small $(\leq 1.5 \mathrm{ml})$, so only the most abundant taxa could be counted accurately using this method. Ciliates and dinoflagellates were present at low densities, so these groups were counted only in the larger-volume microscope subsamples. Cells 7-15 $\mu \mathrm{m}$ were counted only in Expts 2 and 3 ; all other cells counted were $>15 \mu \mathrm{m}$ on their longest axis.

Clearance and ingestion rates were calculated for each taxon using the equations of Marin et al. (1986). Clearance rate was calculated by fitting a generalized linear model with a Poisson error distribution to the cell counts in the final control and treatment bottles using the 'glm' function in the 'stats' package in R. Ingestion rates were calculated by multiplying clearance rates by mean concentrations of cells in initial bottles; $95 \%$ confidence intervals of mean ingestion were calculated by accounting for variance of the clearance rates as well as variance of the mean of the initial cell concentrations. Carbon content of cells was estimated by converting average cell dimensions to biovolume using the conversion factors in Hillebrand et al. (1999), then converting biovolume to carbon using the relationships in Menden-Deuer \& Lessard (2000) (Table A1 in Appendix 1). Average cell dimensions were calculated using automated 
measurements of length and width. At least 30 cell images were selected for each cell type to calculate average measurements. For centric diatoms, sideview images were selected so that the height of the cells could be measured. Ciliate and dinoflagellate dimensions were measured using a calibrated ocular micrometer on the inverted microscope at $400 \times$ magnification.

Population clearance rates $\left(\mathrm{d}^{-1}\right)$, the daily fraction of the prey populations consumed by the entire predator population (Uye 1986), were calculated by extrapolating clearance rates of adult females to mean summer-autumn populations of each copepod species (as in Slaughter et al. 2016) using abundance data from the IEP zooplankton monitoring program. Abundance of each gross life stage (nauplius, copepodite, and adult) was averaged from June-October of 2000-2014. P. forbesi abundance was averaged across the freshwater stations $(\mathrm{S} \leq 0.5)$, and Limnoithona abundance was averaged across stations in the LSZ ( $\mathrm{S}=0.5-5)$. Prey selection was assumed to be the same across life stages but scaled with carbon mass of the copepods. Prey selection of the $P$. forbesi congener $P$. marinus in the SFE is similar between nauplii and adults (Vogt et al. 2013). The same is true for adults and nauplii of Oithona davisae in the SFE (Vogt et al. 2013), a copepod in the same family as $L$. tetraspina and of similar size and predatory mode (Bouley \& Kimmerer 2006).

To determine population biomass, we multiplied mean abundance by a representative carbon value for each gross life stage and summed the 3 products. Carbon biomass of adult and copepodite stages was measured in our laboratory (Gould \& Kimmerer 2010, W. Kimmerer unpubl.). Carbon biomass of nauplii was calculated by fitting an exponential regression from egg carbon (Kimmerer et al. 2014b) to CI carbon (Gould \& Kimmerer 2010) assuming that eggs, NI, and NII have the same carbon biomass. We crosschecked this calculation using a published scaling ratio for P. marinus (Vogt et al. 2013) and got a similar result $(<3 \%$ difference). Clearance rates of adult females were divided by carbon mass to obtain carbonspecific rates which were multiplied by the estimated carbon biomass of each gross stage in the population to calculate a population clearance rate on each prey taxon (Slaughter et al. 2016).

\section{Predation}

Predation on $P$. forbesi nauplii by adult female $L$. tetraspina was tested in an experiment in November
2012. Copepods used in this experiment came from laboratory cultures. The day before the predation experiment, $P$. forbesi cultures were filtered through a $250 \mu \mathrm{m}$ mesh sieve which retained only adults and late copepodites. Copepods were then washed into a PVC cylinder equipped with a $200 \mu \mathrm{m}$ mesh screen and suspended in a 41 bucket containing 31 of culture media. The day of the experiment, the sieve holding adult $P$. forbesi was removed and the remaining water, containing the nauplii that had hatched overnight, was concentrated on a $53 \mu \mathrm{m}$ mesh. Nauplii retained on the mesh were resuspended in GF/F-filtered culture media and sorted under a dissecting microscope into 10 groups of 20 individuals, each a mixture of NII and NIII stages. Groups of nauplii were transferred by pipette into glass vials with $15 \mathrm{ml}$ of GF/F-filtered culture media. Meanwhile, L. tetraspina cultures were concentrated on a $125 \mu \mathrm{m}$ mesh sieve and resuspended in the GF/F-filtered culture media. Adult female L. tetraspina were sorted under a dissecting microscope into groups of 5 and transferred to 7 of the vials; the remaining 3 vials containing only $P$. forbesi nauplii were left as recovery controls. Vials were maintained in the temperature-controlled room at $19^{\circ} \mathrm{C}$ for $28 \mathrm{~h}$ (Table 1). At the end of this time, copepods were stained, preserved, and counted as in the acute salinity tolerance experiments. Clearance rate and population clearance rate were calculated as described for the other feeding experiments.

\section{RESULTS}

\section{Distribution}

During 1989-1992, abundance of Pseudodiaptomus forbesi in the long-term monitoring data exceeded 100,25 , and $10 \%$ of the annual freshwater median abundance at salinities up to 9,15 , and 17 respectively (Fig. 1a, and see Table S1 in the Supplement). During 1993-2016, the population contracted upestuary so that the corresponding salinity values were 3,5 , and 7 , respectively. The annual values (means $\pm 95 \%$ CIs) did not overlap any of those in 1989-1992 (Fig. 1a). Calculations using the full data set or other reductions of the data gave similar results (Fig. S1, Table S1). Over the same time period and in the same sample set, chlorophyll concentration in freshwater exceeded that in the LSZ by $1.3 \pm 0.5 \mu \mathrm{g}$ $\mathrm{l}^{-1}$ with no temporal trend, and annual mean chlorophyll values in each zone varied interannually but also with no trend (Fig. 1b). 

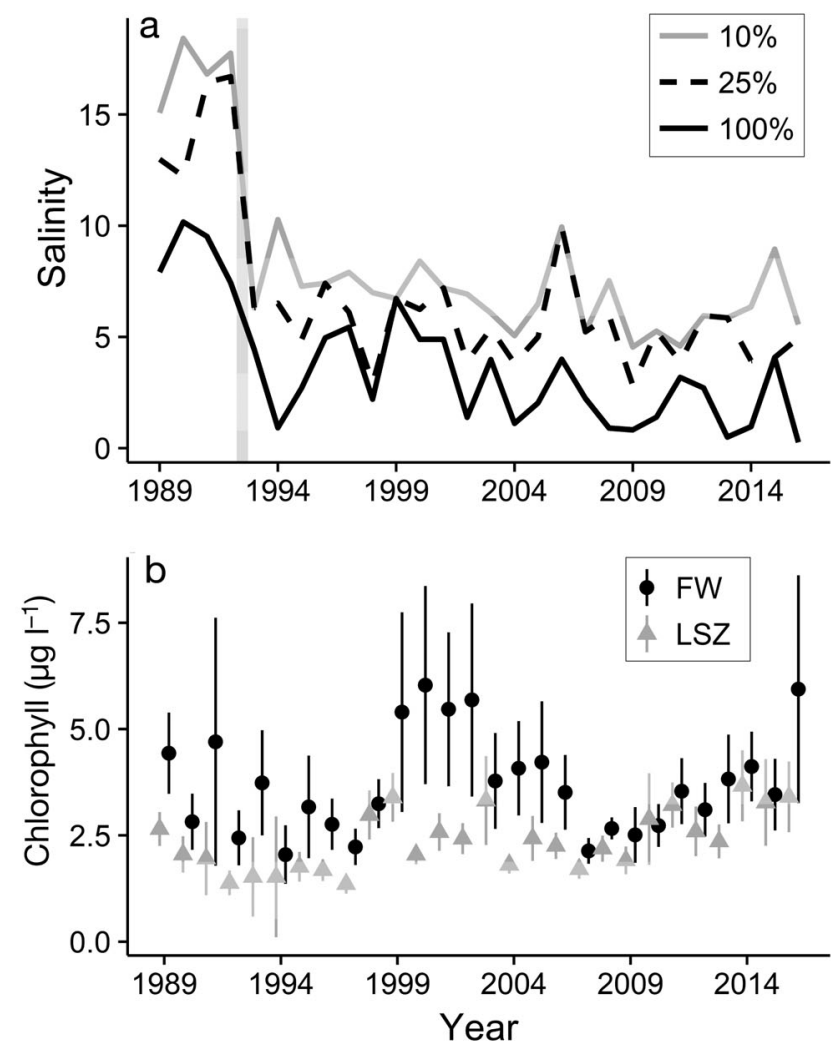

Fig. 1. Temporal variability of distribution in salinity space of Pseudodiaptomus forbesi adults, and chlorophyll concentrations in the upper San Francisco Estuary, June-October 1989-2016. (a) Maximum salinity at which abundance exceeded 10\% (grey line), 25\% (dashed line), or 100\% (black line) of the annual median for all freshwater samples (salinity, $\mathrm{S}<0.5$ ). Mean values of the 10,25 , and $100 \%$ values were $17.0 \pm 2.3(95 \% \mathrm{CI}), 14.6 \pm 3.7$, and $8.8 \pm 2.1$, respectively, for 1989-1992 and 6.8 $\pm 0.6,5.4 \pm 0.7$, and $2.8 \pm 0.8$, respectively, for 1993-2014. (b) Annual means with $95 \%$ CIs of chlorophyll concentration at stations in fresh water (FW,

$\mathrm{S}<0.5$ ) and in the low-salinity zone (LSZ, $\mathrm{S}=0.5-5$ )

\section{Salinity effects}

Mean survival of adults in the $48 \mathrm{~h}$ salinity-shock experiment was high (above $93 \%$ ) at all salinity levels from 0 through 8 (Fig. 2a). Survival declined above salinity 8 (as shown by the declining confidence intervals from the generalized linear model), and mean survival in the salinity 16 treatment was $61 \%$. Nauplii were less susceptible to salinity shock than adults over the range of salinities tested. The generalized linear model fit to the data for nauplii (Fig. 2b) predicted survival above $95 \%$ at all treatment levels tested.

The clutches produced in the low salinities 0.1 and 2 were smaller than at higher salinities of 5,8 , and 12 (Table 3). An analysis of variance (ANOVA) yielded

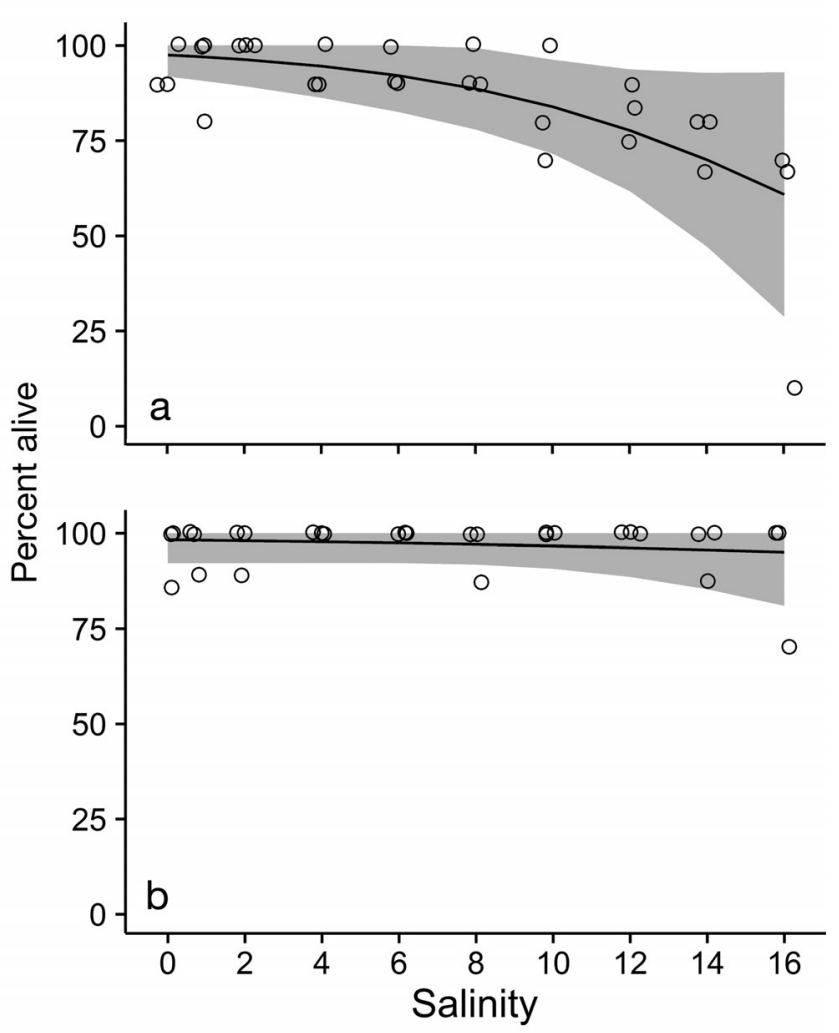

Fig. 2. Percent of Pseudodiaptomus forbesi (a) adults and (b) nauplii alive after $48 \mathrm{~h}$ salinity shock treatment. Circles show data from each replicate with points moved slightly on the $x$-axis to reveal overlapping data points. Lines are predicted means from a generalized linear model with a binomial error distribution. Shading shows the $95 \%$ confidence interval for the model

significant variation among treatments $\left(F_{4,117}=14.0\right.$, $\mathrm{p}<0.01$ ). A Tukey HSD post hoc test showed significant differences between clutch sizes at salinity 0.1 and all other treatments $(\mathrm{p}<0.03)$, and between salinities 5 and 2 (mean difference $5.8 \pm 4.4$ [95\% CI], $\mathrm{p}<0.01$ ). Differences between clutch sizes at the higher salinity treatments were not statistically significant. The largest average clutch size and highest hatching success were in the salinity 5 treatment (Table 3). Overall hatching success was high and there was no trend.

\section{Feeding and predation}

Clearance rates of $P$. forbesi were higher on centric diatoms than on other cell types (Fig. 3), especially in Expts 1 and 3 when initial concentrations of diatoms were much higher than in the other experiments (Table 4). Clearance rates on cells in the 7-15 $\mu \mathrm{m}$ size class were consistently low, despite the order of mag- 
Table 3. Total clutch size and hatching success of Pseudodiaptomus forbesi in 5 salinity treatments. Mean number of eggs clutch $^{-1}$, mean number of dead or unhatched nauplii with $95 \%$ confidence intervals $\left(\mathrm{CI}_{i} \mathrm{~N}=22-28\right.$ ovigerous females treatment ${ }^{-1}$ ). Mean hatching success as percent. ANOVA yielded significant variation among treatments $\left(F_{4,117}=14.0, \mathrm{p}<0.01\right)$. A Tukey HSD test showed significant differences between clutch sizes at salinities 0.1 and 2 $(\mathrm{p}<0.03)$, and salinities 2 and $5(\mathrm{p}<0.01)$; differences between the higher salinity treatments were not statistically significant

\begin{tabular}{|lcccc|}
\hline $\begin{array}{l}\text { Treatment } \\
\text { salinity }\end{array}$ & $\mathrm{N}$ & $\begin{array}{c}\text { Mean } \pm \mathrm{CI} \\
\text { eggs } \\
\text { clutch }^{-1}\end{array}$ & $\begin{array}{c}\text { Mean } \pm \text { CI dead } \\
\text { or unhatched } \\
\text { nauplii }\end{array}$ & $\begin{array}{c}\text { Hatching } \\
\text { success } \\
(\%)\end{array}$ \\
\hline 0.1 & 28 & $16.8 \pm 2.5$ & $1.3 \pm 1.2$ & 92.3 \\
2 & 22 & $21.5 \pm 2.9$ & $2.1 \pm 1.3$ & 90.1 \\
5 & 24 & $27.4 \pm 1.8$ & $0.7 \pm 0.9$ & 97.4 \\
8 & 24 & $23.6 \pm 1.6$ & $1.8 \pm 1.1$ & 92.6 \\
12 & 24 & $24.6 \pm 2.2$ & $1.7 \pm 1.2$ & 93.0 \\
\hline
\end{tabular}

nitude higher abundance of these cells than those in the large size class (Table 4). Overall, P. forbesi appeared to consume a wide variety of cell types but ingested the most carbon in the form of centric diatoms, flagellates, and ciliates (Fig. 4). Population clearance rates of $P$. forbesi were $\sim 12-27 \% \mathrm{~d}^{-1}$ on centric diatoms, $\sim 4-10 \% \mathrm{~d}^{-1}$ on flagellates, and $\sim 6-16 \% \mathrm{~d}^{-1}$ on ciliates (Table 5).

Calculated clearance rates of Limnoithona tetraspina were positive on flagellates $>15 \mu \mathrm{m}$ and ciliates, and negative for all other cell types (Fig. 3). A potential interpretation of negative clearance rates is proposed below. Despite slightly lower clearance rates on flagellates compared to ciliates, most of the carbon ingested by $L$. tetraspina came from flagellates (Fig. 4) because they were much more abundant (Table 4). Population clearance rates were $\sim 8 \%$ $\mathrm{d}^{-1}$ on ciliates and $4-7 \% \mathrm{~d}^{-1}$ on flagellates (Table 5).

Prey disappearance in the predation experiment was very low. Nineteen of the 20 P. forbesi nauplii originally stocked were recovered from 2 of the experimental vials, and all 20 nauplii were recovered from the remaining 5 experimental vials and the 3 recovery control vials. The small change in numbers of nauplii could have been due to error in counting the nauplii or transferring the small nauplii into or out of the vials rather than to predation. Under the assumption that the missing nauplii were removed by predation, we calculated a mean clearance rate of $0.04 \mathrm{ml} \mathrm{d}^{-1}$ (L. tetraspina) $)^{-1}$. The resulting population clearance rate at mean autumn densities of L. tetraspina is negligible at only $0.07 \% \mathrm{~d}^{-1}$.

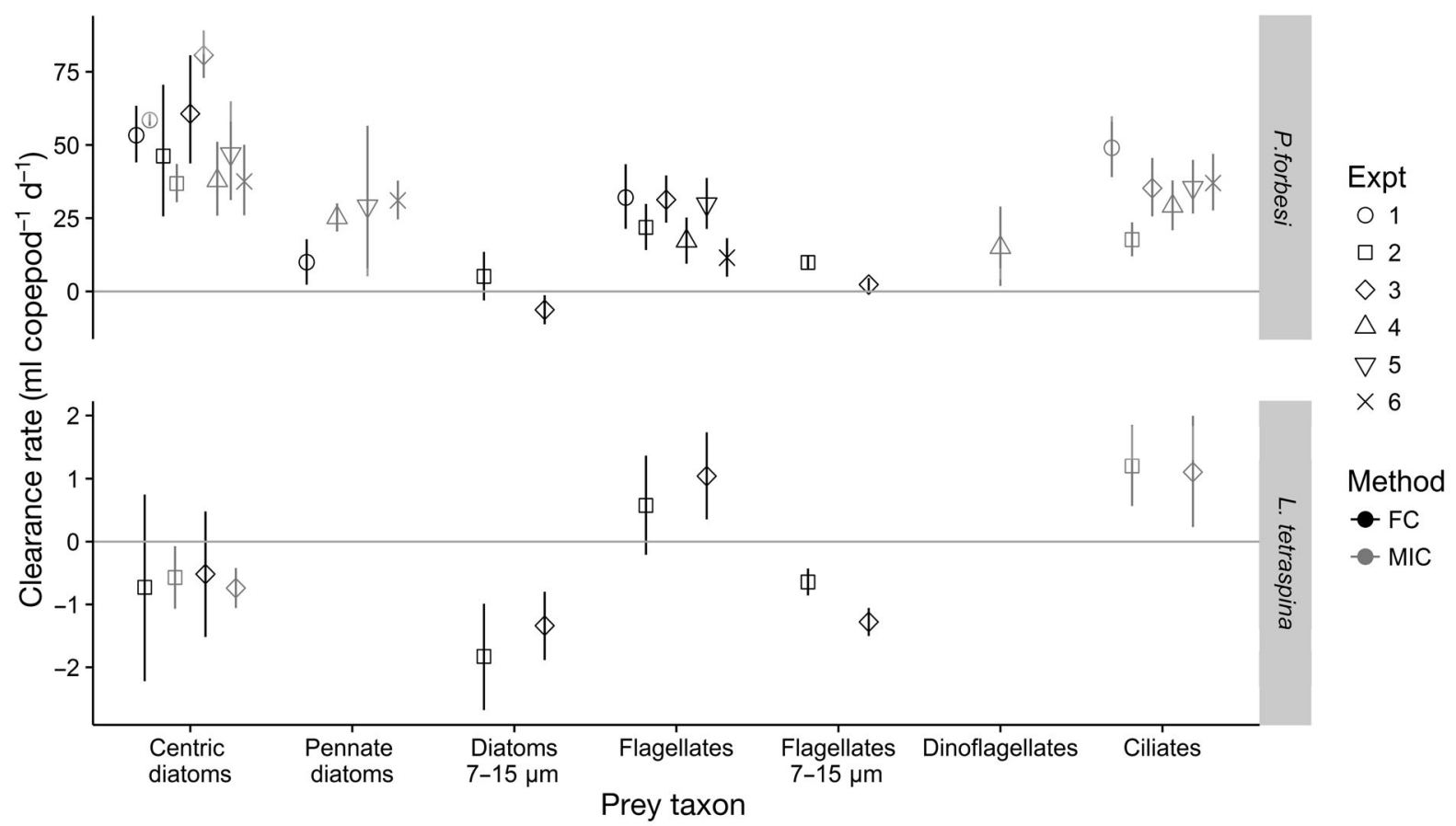

Fig. 3. Clearance rates of Pseudodiaptomus forbesi (top) and Limnoithona tetraspina (bottom) on different prey taxa in 6 experiments. Symbols represent the experiment; black denotes cells counted with the FlowCAM (FC) and grey shows cells counted on an inverted microscope (MIC). Points are means calculated by fitting a generalized linear model with Poisson error distribution to the experimental data; bars show the $95 \%$ confidence intervals. For taxa other than 'Diatoms $7-15 \mu \mathrm{m}$ ' and 'Flagellates $7-15 \mu \mathrm{m},{ }^{\prime}$ cells in each category are $>15 \mu \mathrm{m}$ on their longest axis 
Table 4. Abundance of microplankton taxa (cells ml ${ }^{-1}$; mean $\pm 95 \% \mathrm{CI}$ ) in initial, control, and treatment bottles from all feeding experiments. Shaded counts from FlowCAM, unshaded counts from microscopy. Blank fields indicate taxa not present or not counted

\begin{tabular}{|c|c|c|c|c|c|c|c|c|c|}
\hline \multirow{2}{*}{$\begin{array}{l}\text { Expt } \\
1\end{array}$} & \multirow{2}{*}{$\begin{array}{l}\text { Type } \\
\text { Initial }\end{array}$} & \multicolumn{2}{|c|}{ Centric diatoms } & \multirow{2}{*}{$\begin{array}{c}\text { Pennate } \\
\text { diatoms }\end{array}$} & \multirow{2}{*}{$\begin{array}{l}\text { Diatoms } \\
7-15 \mu \mathrm{m}\end{array}$} & \multirow{2}{*}{$\begin{array}{l}\text { Flagellates } \\
34.5 \pm 6.7\end{array}$} & \multirow{2}{*}{$\begin{array}{c}\text { Flagellates } \\
7-15 \mu \mathrm{m}\end{array}$} & \multirow{2}{*}{$\begin{array}{l}\text { Dino- } \\
\text { flagellates }\end{array}$} & Ciliates \\
\hline & & $19.5 \pm 2.4$ & $23.1 \pm 6.4$ & & & & & & $1.0 \pm 0.3$ \\
\hline & Control & $33.5 \pm 5.9$ & $43.1 \pm 3.2$ & $22.1 \pm 3.2$ & & $18.2 \pm 5.9$ & & & $1.0 \pm 1.2$ \\
\hline & Pseudodiaptomus forbesi & $4.5 \pm 4.6$ & $6.9 \pm 4.6$ & $15.7 \pm 6.0$ & & $6.1 \pm 2.2$ & & & $0.2 \pm 0.1$ \\
\hline 2 & Initial & $2.3 \pm 0.7$ & $9.1 \pm 8.1$ & & $15.0 \pm 8.4$ & $112 \pm 26.5$ & $261 \pm 55.1$ & & $1.5 \pm 0.5$ \\
\hline & Control & $3.5 \pm 0.6$ & $6.6 \pm 2.2$ & & $17.7 \pm 3.2$ & $27.9 \pm 13.3$ & $316 \pm 56.5$ & & $2.8 \pm 0.4$ \\
\hline & P. forbesi & $1.0 \pm 0.9$ & $1.4 \pm 1.5$ & & $14.9 \pm 2.9$ & $13.2 \pm 4.2$ & $225 \pm 54.5$ & & $1.5 \pm 0.7$ \\
\hline & Limnoithona tetraspina & $4.1 \pm 0.7$ & $8.1 \pm 2.3$ & & $29.9 \pm 9.3$ & $23.6 \pm 6.0$ & $379 \pm 111$ & & $2.0 \pm 0.6$ \\
\hline 3 & Initial & $4.7 \pm 1.3$ & $6.9 \pm 3.2$ & & $19.3 \pm 4.3$ & $79.7 \pm 18.0$ & $648 \pm 54.8$ & & $1.1 \pm 0.6$ \\
\hline & Control & $8.4 \pm 0.6$ & $14.9 \pm 5.0$ & & $54.3 \pm 6.8$ & $44.8 \pm 38.1$ & $321 \pm 84.8$ & & $1.4 \pm 0.4$ \\
\hline & P. forbesi & $0.5 \pm 0.2$ & $1.9 \pm 1.6$ & & $67.3 \pm 12.6$ & $15.3 \pm 5.1$ & $296 \pm 146$ & & $0.4 \pm 0.1$ \\
\hline & L. tetraspina & $10.4 \pm 1.2$ & $17.2 \pm 4.4$ & & $79.6 \pm 8.2$ & $33.3 \pm 9.3$ & $463 \pm 56.7$ & & $1.1 \pm 0.6$ \\
\hline 4 & Initial & $1.7 \pm 0.1$ & & $6.4 \pm 1.1$ & & $61.3 \pm 19.5$ & & $0.6 \pm 0.1$ & $1.1 \pm 0.3$ \\
\hline & Control & $1.2 \pm 0.5$ & & $5.9 \pm 0.9$ & & $39.8 \pm 9.4$ & & $0.6 \pm 0.1$ & $2.1 \pm 0.3$ \\
\hline & P. forbesi & $0.3 \pm 0.2$ & & $2.5 \pm 0.8$ & & $22.0 \pm 2.2$ & & $0.3 \pm 0.1$ & $0.8 \pm 0.5$ \\
\hline 5 & Initial & $0.6 \pm 0.3$ & & $0.7 \pm 0.3$ & & $65.1 \pm 11.2$ & & & $1.4 \pm 0.3$ \\
\hline & Control & $0.7 \pm 0.3$ & & $0.2 \pm 0.03$ & & $44.1 \pm 21.7$ & & & $1.7 \pm 0.3$ \\
\hline & P. forbesi & $0.1 \pm 0.1$ & & $0.1 \pm 0.1$ & & $15.9 \pm 5.8$ & & & $0.5 \pm 0.2$ \\
\hline 6 & Initial & $1.1 \pm 0.4$ & & $1.9 \pm 0.9$ & & $66.7 \pm 24.7$ & & & $0.9 \pm 0.4$ \\
\hline & Control & $1.1 \pm 0.2$ & & $2.9 \pm 1.3$ & & $50.3 \pm 3.8$ & & & $1.6 \pm 0.8$ \\
\hline & P. forbesi & $0.3 \pm 0.1$ & & $1.0 \pm 0.8$ & & $33.9 \pm 7.1$ & & & $0.5 \pm 0.3$ \\
\hline
\end{tabular}

\section{DISCUSSION}

The persistence of organisms in any habitat depends on their responses to environmental conditions and interspecific interactions. Salinity is the classical driving force of estuarine species' distributions, but physical factors such as temperature, turbidity, and habitat structure often covary with salinity, as do biological factors such as food availability and the distribution of predators and competitors. All of these factors have been invoked to explain distribution patterns of zooplankton (Lakkis 1994, Lee et al. 2013). What caused the shift in distribution of Pseudodiaptomus forbesi after 1993, and why is it now confined largely to fresh water? We explore 3 potential explanations: change in salinity tolerance, bottom-up effects through competition with introduced species, and top-down effects through predation pressure from introduced species.

\section{Abiotic control: salinity effects}

The effects of salinity on the mortality or reproduction of this species have not previously been investigated in any system, and the only relevant information on salinity effects is on distribution (Orsi \& Walter 1991, Cordell et al. 2008, Bollens et al. 2012).
Our laboratory results are consistent with field observations of the distribution of the species before but not after the introductions in 1993 (Fig. 1a) and reported distributions in other estuaries. In the Columbia River Estuary, P. forbesi is found from the brack-

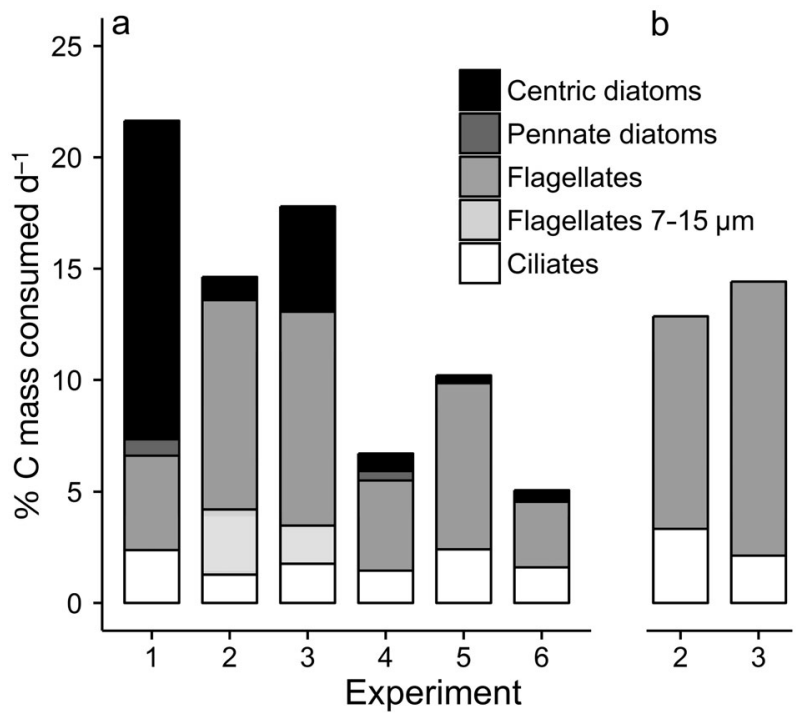

Fig. 4. Ingestion expressed as daily fraction for (a) Pseudodiaptomus forbesi and (b) Limnoithona tetraspina on different taxa. Proportion of carbon ingested $\mathrm{d}^{-1}$ to biomass of the copepods: adult female $P$. forbesi $4.26 \mu \mathrm{g} \mathrm{C}$ (Kimmerer unpubl.), and adult female L. tetraspina $0.11 \mu \mathrm{g} \mathrm{C}$ (Gould \& Kimmerer 2010). Ingestion rates $<0.2 \% \mathrm{~d}^{-1}$ are not plotted 
Table 5. Population clearance (\%) of water volume cleared $\mathrm{d}^{-1}$ by each copepod species on each prey taxon (mean $\pm 95 \%$ CI). Shaded counts from FlowCAM, unshaded counts from microscopy. Blank fields indicate taxa not present or not counted. Neg: experiment-taxon combinations where calculated clearance rates were negative and therefore were not used in further calculations

\begin{tabular}{|c|c|c|c|c|c|c|c|c|c|}
\hline \multirow{2}{*}{$\begin{array}{l}\text { Species } \\
\text { Pseudodiaptomus forbesi }\end{array}$} & \multirow{2}{*}{$\begin{array}{c}\text { Expt } \\
1\end{array}$} & \multicolumn{2}{|c|}{ Centric diatoms } & \multirow{2}{*}{$\begin{array}{c}\begin{array}{c}\text { Pennate } \\
\text { diatoms }\end{array} \\
3.3 \pm 2.6\end{array}$} & \multirow{2}{*}{$\begin{array}{l}\text { Diatoms } \\
7-15 \mu \mathrm{m}\end{array}$} & \multirow{2}{*}{$\begin{array}{l}\text { Flagellates } \\
10.6 \pm 3.8\end{array}$} & \multirow{2}{*}{$\begin{array}{l}\text { Flagellates } \\
7-15 \mu \mathrm{m}\end{array}$} & \multirow{2}{*}{$\begin{array}{l}\text { Dino- } \\
\text { flagellates }\end{array}$} & \multirow{2}{*}{$\begin{array}{r}\text { Ciliates } \\
16.2 \pm 3.5\end{array}$} \\
\hline & & $19.3 \pm 0.7$ & $17.6 \pm 3.3$ & & & & & & \\
\hline & 2 & $12.1 \pm 2.2$ & $15.2 \pm 8.0$ & & $1.7 \pm 2.7$ & $7.2 \pm 2.6$ & $3.3 \pm 0.7$ & & $5.8 \pm 1.9$ \\
\hline & 3 & $26.6 \pm 2.8$ & $20.0 \pm 6.6$ & & Neg & $10.3 \pm 2.7$ & $0.8 \pm 0.7$ & & $11.6 \pm 3.4$ \\
\hline & 4 & $12.5 \pm 4.4$ & & $8.3 \pm 1.6$ & & $5.7 \pm 2.6$ & & $4.9 \pm 2.9$ & $9.6 \pm 2.9$ \\
\hline & 5 & $15.5 \pm 5.9$ & & $9.6 \pm 9.0$ & & $9.8 \pm 2.9$ & & & $11.7 \pm 3.1$ \\
\hline & 6 & $12.4 \pm 4.1$ & & $10.2 \pm 2.2$ & & $3.8 \pm 2.2$ & & & $12.2 \pm 3.3$ \\
\hline \multirow[t]{2}{*}{ Limnoithona tetraspina } & 2 & Neg & Neg & & Neg & $4.1 \pm 5.6$ & Neg & & $8.6 \pm 4.6$ \\
\hline & 3 & Neg & $\mathrm{Neg}$ & & $\mathrm{Neg}$ & $7.4 \pm 4.9$ & Neg & & $7.9 \pm 6.3$ \\
\hline
\end{tabular}

ish lower estuary up into the Snake River tributary (Cordell et al. 2008), and high abundances of $P$. forbesi have been recorded at salinities from 0-12 (Bollens et al. 2012). In its native range in the Yangtze River and estuary in China, $P$. forbesi is found in salinities up to at least 8 (Orsi \& Walter 1991).

We found no evidence that physiological tolerance to salinity restricts $P$. forbesi to fresh water in the upper SFE. In fact, our data suggest the opposite: $P$. forbesi seemed physiologically better adapted to live in brackish water than in fresh. Survival of adult females was high up to salinity 8 ; although we did not test survival of males, the proportion of males in samples from salinity $0.5,2$, and 5 in 2006-2007 averaged 0.6 and did not vary by salinity (based on data from Kimmerer et al. 2014b), implying similar survival of both sexes. Naupliar survival was near $100 \%$ at least up to salinity 14 (Fig. 2). Reproduction was significantly higher at salinity 5 than at salinities of 0.1 or 2 (Tukey's HSD, p < 0.01), with a higher mean than in any other treatments (Table 3). Both clutch size and hatching success were numerically highest in the salinity 5 treatment. These results are similar to findings for Eurytemora affinis populations that have invaded freshwater habitats (Lee et al. 2013). Chlorophyll concentrations were elevated by $\sim 1.3 \mu \mathrm{g} \mathrm{l}^{-1}$ in fresh water over values in the LSZ, suggesting additional capacity for $P$. forbesi to overcome salinity stress in fresh water (Lee et al. 2013). However, the lack of trend in the chlorophyll data fails to support the hypothesis that a change in food supply was instrumental in the spatial shift of $P$. forbesi. We do not know whether salinity tolerance of $P$. forbesi has changed since its introduction.

Estuarine copepod populations typically are most abundant within a species-specific range of salinity (Miller 1983). Although this pattern is often attributed to salinity tolerance, the observed distributions are frequently inconsistent with the copepods' physiological responses to salinity (Rippingale \& Hodgkin 1975). For example, members of the global species complex $E$. affinis are most often found in freshwater to low-salinity regions of estuaries (Lee 2000), but experiments have invariably shown good survival, reproduction, or growth across a wide range of salinity (Roddie et al. 1984, Nagaraj 1992, Kimmel \& Bradley 2001, Devreker et al. 2012). Furthermore, a favorable feeding environment can enable an animal to acclimate to salinity outside its optimum range (Lee et al. 2013). Therefore, the distribution of a copepod species in salinity space likely arises through a combination of salinity tolerance with behaviorally mediated retention mechanisms (Hough \& Naylor 1991, Simons et al. 2006, Kimmerer et al. 2014a) and spatially variable growth and mortality (Barlow 1955, Stalder \& Marcus 1997, Tiselius et al. 2008) that may offset effects of unfavorable salinity (Lee et al. 2013, Hammock et al. 2016) or restrict distributions to only part of the tolerated range (Rippingale \& Hodgkin 1975).

\section{Biotic control: food availability}

Since open-water zooplankton are too dilute to be limited by space, the main resource axis on which they compete is food. Evidence for competition in zooplankton is difficult to find, especially in estuaries. In most cases, competition between zooplankton species is inferred from variation in body size, seasonal occurrence, or spatial distributions with and without a potential competitor (Tranter \& Abraham 1971, Vanni 1986, Urabe 1990). Often, competition is inferred from spatial overlap of species and assumptions that they have overlapping diets (Rothhaupt 1990, Lakkis 1994, Bollens et al. 2012). However, 
overlaps are insufficient evidence to demonstrate competition. Grazing by a superior competitor must limit the abundance of food available to the lesser competitor in order for competition to be invoked as a major influence on the latter's population dynamics. There are few examples in the literature where this effect has been demonstrated. Larger cladocerans dominate in lakes without fish because they consume so much phytoplankton that the smaller cladocerans are deprived of food. This was attributed to competition because experimental nutrient additions, by increasing the growth of phytoplankton, led to increases in the abundance of the smaller cladoceran species (Vanni 1986).

In the LSZ of the SFE, the major consumers of large phytoplankton and microzooplankton are copepods and the invasive Asian overbite clam Potamocorbula amurensis (Greene et al. 2011, Kimmerer \& Thompson 2014, York et al. 2014). The invasive clam is implicated in substantially drawing down phytoplankton biomass in the LSZ since its introduction in 1987 (Alpine \& Cloern 1992). Grazing by clams, copepods, and microzooplankton on phytoplankton in the LSZ usually outpaces production (Kimmerer \& Thompson 2014). The clam P. amurensis may consume 50 to $90 \%$ of ciliates $\mathrm{d}^{-1}$ (Greene et al. 2011) which can exceed maximum population growth rates of the microzooplankton. Ciliate growth rates in this study, calculated from the log ratio of abundance in the $24 \mathrm{~h}$ controls to initial abundance (Table 4), were $0-60 \%$ $\mathrm{d}^{-1}$ in the absence of copepods. The invasive clam is thus a primary competitor of planktivores in the SFE, with the potential to both directly and indirectly cause declines in zooplankton (Kimmerer et al. 1994, Kimmerer \& Orsi 1996, Kimmerer 2006, Kimmerer \& Lougee 2015).

Overall $P$. forbesi appears to be a generalist, consuming whatever cells are abundant (York et al. 2014). Limnoithona tetraspina specializes on motile prey (Bouley \& Kimmerer 2006, Gifford et al. 2007, York et al. 2014), so any competition with $P$. forbesi is limited to those prey types; in this study, these were flagellates and ciliates. Although both copepods consumed motile prey, $P$. forbesi also consumed considerable amounts of centric diatoms when abundant (Fig. 4). In the Columbia River Estuary, P. forbesi also ingests most of its carbon from diatoms and ciliates, at rates comparable to those found in this study (Bowen et al. 2015). Prey selection and clearance rates of $L$. tetraspina reported here are comparable to rates from previous studies in the SFE (Bouley \& Kimmerer 2006, York et al. 2014), despite differences in prey density (Bouley \&
Kimmerer 2006). Predation on ciliates by both copepod species likely triggered a trophic cascade (York et al. 2014), depressing calculated clearance rates on cells that would have been consumed by ciliates. For L. tetraspina this is particularly evident, as experiments consistently yielded negative clearance rates on diatoms and on flagellates 7-15 $\mu \mathrm{m}$. We must assume then that clearance rates for $P$. forbesi on those cell types are underestimates.

The mean population clearance rates of L. tetraspina on flagellates $>15 \mu \mathrm{m}$ and on ciliates were about $4-8 \% d^{-1}$ (Table 5). During 2006-2007, the population clearance of phytoplankton biomass $>5 \mu \mathrm{m}$ by clams, microzooplankton, and copepods during summer in the LSZ was estimated at 26, 14, and $4 \% \mathrm{~d}^{-1}$, respectively (data from Kimmerer \& Thompson 2014). Thus, the daily consumption of phytoplankton and microzooplankton by $L$. tetraspina is a small part of the overall consumption of each. Although low food availability may limit growth and reproductive rates of both $P$. forbesi (Kimmerer et al. 2014b) and $L$. tetraspina (Gould \& Kimmerer 2010), and lack of suitable food can exclude copepods from areas that are otherwise suitable (Modéran et al. 2012), the competitive effect of $L$. tetraspina on $P$. forbesi appears negligible. Moreover, growth rates of $P$. forbesi were similar among salinities of $0.5,2$, and 5 in 2006-2007 (Kimmerer et al. 2014b), suggesting similar trophic conditions across the salinity gradient.

Higher food concentrations in fresh water have facilitated invasions of $E$. affinis into freshwater habitats (Lee et al. 2013) by providing the invader with the energy needed for osmoregulation and ion uptake (Lee et al. 2012). With sufficient food, brackishadapted species tend to grow faster and have higher fecundity than freshwater species (Peterson 2001), giving them an advantage over freshwater species and allowing them to successfully invade freshwater habitats. However, the elevation of chlorophyll concentration in fresh water over that in the LSZ was rather small and inconsistent among years (Fig. 1b).

\section{Biotic control: predation}

Selective predation can exert powerful top-down effects that shape pelagic communities (Brett \& Goldman 1997, Cloern \& Dufford 2005), mediated through both direct and indirect effects on the distribution of prey species. Predators may remove a species from a potential niche directly through consumption (Rippingale \& Hodgkin 1975, Kimmerer \& McKinnon 1989, Kimmerer 1991), or may induce migration or 
other predator-avoidance behaviors that change the distribution of prey species (Fancett \& Kimmerer 1985, Bollens et al. 1992).

A conservative estimate of the mortality rate that $P$. forbesi nauplii could withstand while maintaining a stable population, based on growth rate and specific egg production, is $\sim 25 \% \mathrm{~d}^{-1}$. We calculated this estimate (see Kimmerer \& Lougee 2015) using the development times of nauplii $\left(D_{\mathrm{n}}\right)$ and copepodites $\left(D_{\mathrm{c}}\right)$ (Kimmerer \& Gould 2010), the egg production rate (EPR) of the adult females (Kimmerer et al. 2014b), and an estimate of the mortality rate of adults $\left(M_{\mathrm{a}}\right)$. $M_{\mathrm{a}}$ was calculated by dividing the ratio of copepodites $\left(N_{\mathrm{c}}\right)$ to adults $\left(N_{\mathrm{a}}\right)$ in the population by the development time of the copepodites $\left(D_{\mathrm{c}}\right)$,

$$
M_{\mathrm{a}}=\frac{N_{\mathrm{c}}}{N_{\mathrm{a}} D_{\mathrm{c}}}
$$

This assumes that there is no mortality of copepodites, an assumption that yields the maximum mortality of nauplii, and that the population is at steady state. The ratio of adults to copepodites was calculated from the same monitoring data used for estimating population clearance rates.

To maintain the population at steady state, the rate of production of nauplii (EPR) multiplied by the rate of survival to adults must be enough to equal the number of adults that die each day, calculated as the population of adults $\left(N_{\mathrm{a}}\right)$ times the mortality rate of the adults $\left(M_{\mathrm{a}}\right)$ (Hirst \& Kiørboe 2002). Again, we assumed no mortality of copepodites, and estimated the maximum mortality of nauplii that would allow for steady state,

$$
M_{\mathrm{a}}=-\ln \left(\frac{M_{\mathrm{a}}}{0.5 \cdot \mathrm{EPR}}\right) \frac{1}{D_{\mathrm{n}}}
$$

In reality there is some mortality of copepodites, which would require a downward adjustment in the estimated maximum mortality of nauplii. But there are also subsidies of nauplii and ovigerous females by dispersion from fresh water, which would allow for higher mortality than estimated. Since the relative magnitude of these adjustments is unknown, we used the $\sim 25 \% \mathrm{~d}^{-1}$ estimate.

The major predators of $P$. forbesi in the LSZ are the clam P. amurensis (Kimmerer \& Lougee 2015) and the predatory copepod Acartiella sinensis (Slaughter et al. 2016). Feeding rates of fish on $P$. forbesi have not been published, but abundance of planktivorous fishes is low in the upper SFE (Sommer et al. 2007) so their predatory impact is probably also low. Small oithonids such as Oithona nana are capable of eating calanoid nauplii (Lampitt 1978, Lampitt \& Gamble
1982). However, consumption of calanoid nauplii by $L$. tetraspina is negligible, as shown with $P$. forbesi in this study, and E. affinis previously (Bouley \& Kimmerer 2006).

Benthic grazing likely exerts considerable control on the abundance of $P$. forbesi where the copepod and the clam $P$. amurensis co-occur. Estimated longterm mean population clearance of $P$. amurensis on $E$. affinis nauplii varied seasonally from 4 to $23 \% \mathrm{~d}^{-1}$, with a minimum in spring and a maximum in autumn; during July-October when $P$. forbesi is highly abundant, the mean clearance rate was estimated at $\sim 14 \% \mathrm{~d}^{-1}$ (Kimmerer et al. 1994, Kimmerer \& Lougee 2015). Nauplii of E. affinis are similar in size and behavior to nauplii of $P$. forbesi, and have nearly identical escape rates from artificial clam siphons (Kimmerer \& Lougee 2015), so clearance rates of clams on the 2 copepod species are likely to be similar. Thus, before the introduction of $A$. sinensis, consumption by clams was probably the largest source of predation mortality on $P$. forbesi nauplii in the LSZ, and consumption rates were about half of the maximum mortality the population could withstand without a subsidy. Once $A$. sinensis was introduced to the estuary, it became the other major predator on $P$. forbesi nauplii in the LSZ. Extrapolation of the feeding rates of this predatory copepod to mean long-term summerautumn population densities indicate that it consumes $\sim 12 \%$ of $P$. forbesi nauplii $\mathrm{d}^{-1}$ (Slaughter et al. 2016).

The combined predatory impact of $P$. amurensis and $A$. sinensis exceeds the maximum calculated mortality on nauplii that the population can sustain. Therefore $P$. forbesi can co-occur with these predators only by subsidy from fresh water. The demographic structure of the P. forbesi population in the LSZ supports the subsidy hypothesis. During July-August 2006-2007 the median proportions of nauplii, copepodites, and adults in the LSZ were 51,13 , and $36 \%$, respectively (based on data in Kimmerer et al. 2014b). The low proportion of copepodites together with very low reproductive rates in the LSZ (Kimmerer et al. 2014b) suggest that the population is unsustainable in isolation, and that copepods are being transported from freshwater habitats into the LSZ.

\section{Implications}

Invasions can provide insight into adaptive responses, as native populations may undergo strong selection when interacting with introduced competitors and predators (Yoshida et al. 2007). The invasive clam $P$. amurensis reduced food availability to cope- 
pods in the LSZ and increased mortality through consumption of nauplii (Kimmerer et al. 1994), thus acting as both a competitor and a predator. This effectively eliminated the previously dominant (by numerical abundance and biomass) $E$. affinis, which is now abundant only in winter-spring (Bollens et al. 2011, Kimmerer \& Lougee 2015). P. forbesi was introduced a year after the clam became abundant; although the timing of its initial introduction was no doubt coincidental, the spread of $P$. forbesi may have been facilitated by the elimination of $E$. affinis. $P$. forbesi has a freshwater refuge from clam predation where it can persist during summers when clams are abundant, while E. affinis has been unable to occupy this refuge to any great extent during summer.

The $A$. sinensis population is supported principally by consumption of L. tetraspina (Slaughter et al. 2016); thus, the presence of this abundant prey may have facilitated a relatively high abundance of $A$. sinensis and therefore high population consumption rate of this predator on other prey such as $P$. forbesi. Facilitation, once ignored, is now considered a common and structurally important interaction in ecosystems (Bruno et al. 2003). Examples of facilitation are frequently reported in ecosystems where organisms produce physical structure, such as terrestrial plant communities and coral reefs (Bruno et al. 2003). Diffuse facilitation has also been reported in analogous situations to that reported here, e.g. brown tree snakes in Guam which survive by feeding at low levels on lizards but have decimated bird populations (Fritts \& Rodda 1998), and garter snakes in California supported by feeding on introduced trout but also preying on and reducing the abundance of amphibians (Pope et al. 2008). These 2 cases and that of $A$. sinensis are instances of hyperpredation (Smith \& Quin 1996), by which an abundant prey supports the predator population, which then also preys on the less abundant alternative prey, resulting in population declines.

The concurrent introductions of $A$. sinensis and $L$. tetraspina in 1993 seem to have further intensified the pressures on $P$. forbesi in the LSZ through reduced food availability and increased mortality from predation. These combined pressures may have shifted the seaward limit of the $P$. forbesi distribution to lower salinity (Fig. 1a). According to the calculations presented here along with other literature on the system (Greene et al. 2011, Kimmerer \& Thompson 2014, Slaughter et al. 2016), the additional mortality of nauplii due to consumption by $A$. sinensis apparently is the principal cause of this shift. Direct competition with $L$. tetraspina appears to have a minor im- pact on food supply, and the effects of the clam $P$. amurensis were present before the shift.

A consequence of these changes for the food web of the upper SFE was a reduction in prey abundance for the endangered delta smelt, whose principal prey is P. forbesi (Slater \& Baxter 2014). This species and several other fishes of the region have been in a state of continual decline since $\sim 2002$, at least partly as a result of the declining zooplankton abundance in the LSZ (Sommer et al. 2007). The configuration of the food web has changed little since 1993, suggesting that the decline in food available to delta smelt in the open waters of the estuary is unlikely to be reversed without management intervention. Various proposed remedial actions may help to reverse this decline, such as wetland and floodplain restoration designed to enhance pelagic productivity (Herbold et al. 2014), and research is underway to investigate the efficacy of such actions.

Acknowledgements. We thank A. Slaughter, T. Ignoffo, J. Donald, R. DuMais, A. Johnson, and R. Vogt for help in the field and laboratory, and the captain and crew of the RV 'Questuary.' L. Sullivan and J. Moderan provided guidance on experimental and analytical methods. Zooplankton monitoring data were provided by A. Hennessy (Interagency Ecological Program). M. Weaver provided helpful comments on an earlier version of the manuscript. Funding was provided by the U.S. Dept. of Interior agreement no. R10AC20074. Fluid Imaging Technologies provided a FlowCAM to use for 4 mo as part of an Aquatic Research Student Equipment and Travel Grant.

\section{LITERATURE CITED}

Alpine AE, Cloern JE (1992) Trophic interactions and direct physical effects control phytoplankton biomass and production in an estuary. Limnol Oceanogr 37:946-955

Barlow JP (1955) Physical and biological processes determining the distribution of zooplankton in a tidal estuary. Biol Bull (Woods Hole) 109:211-225

Bennett WA (2005) Critical assessment of the delta smelt population in the San Francisco Estuary, California. S Francisco Estuar Watershed Sci 3(2)

Bennett WA, Moyle PB (1996) Where have all the fishes gone? Interactive factors producing fish declines in the Sacramento-San Joaquin Estuary. In: Hollibaugh JT (ed) San Francisco Bay: the ecosystem. Pacific Division of the American Association for the Advancement of Science, San Francisco, p 519-542

Bollens SM, Frost BW, Thoreson DS, Watts SJ (1992) Diel vertical migration in zooplankton: field evidence in support of the predator avoidance hypothesis. Hydrobiologia 234:33-39

Bollens SM, Breckenridge JK, Hooff RCV, Cordell JR (2011) Mesozooplankton of the lower San Francisco Estuary: spatio-temporal patterns, ENSO effects and the prevalence of non-indigenous species. J Plankton Res 33:1358-1377 
Bollens SM, Breckenridge JK, Cordell JR, Rollwagen-Bollens G, Kalata O, Claudi R, Karatayev A (2012) Invasive copepods in the Lower Columbia River Estuary: seasonal abundance, co-occurrence and potential competition with native copepods. Aquat Invasions 7:101-109

Bouley P, Kimmerer WJ (2006) Ecology of a highly abundant, introduced cyclopoid copepod in a temperate estuary. Mar Ecol Prog Ser 324:219-228

Bowen A, Rollwagen-Bollens G, Bollens SM, Zimmerman J (2015) Feeding of the invasive copepod Pseudodiaptomus forbesi on natural microplankton assemblages within the lower Columbia River. J Plankton Res 37:1089-1094

Brett MT, Goldman CR (1997) Consumer versus resource control in freshwater pelagic food webs. Science 275: 384-386

Bruno JF, Stachowicz JJ, Bertness MD (2003) Inclusion of facilitation into ecological theory. Trends Ecol Evol 18: 119-125

*Blger AJ, Hayden BP, Monaco ME, Nelson DM, McCormick-Ray MG (1993) Biologically-based estuarine salinity zones derived from a multivariate analysis. Estuaries 16:311-322

* Carlton JT, Thompson JK, Schemel LE, Nichols FH (1990) Remarkable invasion of San Francisco Bay (California, USA), by the Asian clam Potamocorbula amurensis. I. Introduction and dispersal. Mar Ecol Prog Ser 66:81-94

* Chen Q, Sheng J, Lin Q, Gao Y, Lv J (2006) Effect of salinity on reproduction and survival of the copepod Pseudodiaptomus annandalei Sewell, 1919. Aquaculture 258: 575-582

* Cloern JE, Dufford R (2005) Phytoplankton community ecology: principles applied in San Francisco Bay. Mar Ecol Prog Ser 285:11-28

Cloern JE, Jassby AD (2012) Drivers of change in estuarinecoastal ecosystems: discoveries from four decades of study in San Francisco Bay. Rev Geophys 50:RG4001

* Cohen AN, Carlton JT (1998) Accelerating invasion rate in a highly invaded estuary. Science 279:555-558

Cordell JR, Bollens SM, Draheim R, Sytsma M (2008) Asian copepods on the move: recent invasions in the Columbia-Snake River system, USA. ICES J Mar Sci 65: 753-758

DeMott WR (1989) The role of competition in zooplankton succession. In: Sommer U (ed) Plankton ecology. Springer, Berlin, p 195-252

Devreker D, Pierson JJ, Souissi S, Kimmel DG, Roman MR (2012) An experimental approach to estimate egg production and development rate of the calanoid copepod Eurytemora affinis in Chesapeake Bay, USA. J Exp Mar Biol Ecol 416-417:72-83

Dressel DM, Heinle DR, Grote MC (1972) Vital staining to sort dead and live copepods. Chesap Sci 13:156-159

Fancett MS, Kimmerer WJ (1985) Vertical migration of the demersal copepod Pseudodiaptomus as a means of predator avoidance. J Exp Mar Biol Ecol 88:31-43

*Fleming JM, Coughlan J (1978) Preservation of vitally stained zooplankton for live/dead sorting. Estuaries 1: 135-137

Fofonoff PW, Ruiz GM, Steves B, Simkanin C, Carlton JT (2017) National Exotic Marine and Estuarine Species Information System. Smithsonian Environmental Research Center, Edgewater. http://invasions.si.edu/nemesis/

Fritts TH, Rodda GH (1998) The role of introduced species in the degradation of island ecosystems: a case history of Guam. Annu Rev Ecol Syst 29:113-140
Gifford DJ (1993) Consumption of protozoa by copepods feeding on natural microplankton assemblages. In: Kemp PF, Cole JJ, Sherr BF, Sherr EB (eds) Handbook of methods in aquatic microbial ecology. CRC Press, Boca Raton, FL, p 723-729

Gifford SM, Rollwagen-Bollens G, Bollens SM (2007) Mesozooplankton omnivory in the upper San Francisco Estuary. Mar Ecol Prog Ser 348:33-46

* Gould AL, Kimmerer WJ (2010) Development, growth, and reproduction of the cyclopoid copepod Limnoithona tetraspina in the upper San Francisco Estuary. Mar Ecol Prog Ser 412:163-177

G Greene VE, Sullivan LJ, Thompson JK, Kimmerer WJ (2011) Grazing impact of the invasive clam Corbula amurensis on the microplankton assemblage of the northern San Francisco Estuary. Mar Ecol Prog Ser 431:183-193

*Hammock BG, Lesmeister S, Flores I, Bradburd GS, Hammock FH, Teh SJ (2016) Low food availability narrows the tolerance of the copepod Eurytemora affinis to salinity, but not to temperature. Estuaries Coasts 39:189-200

Herbold B, Baltz DM, Brown L, Grossinger R and others (2014) The role of tidal marsh restoration in fish management in the San Francisco Estuary. S Francisco Estuar Watershed Sci 12(1)

*Hillebrand H, Dürselen CD, Kirschtel D, Pollingher U, Zohary T (1999) Biovolume calculation for pelagic and benthic microalgae. J Phycol 35:403-424

* Hirst AG, Kiørboe T (2002) Mortality of marine planktonic copepods: global rates and patterns. Mar Ecol Prog Ser 230:195-209

Hobbs JA, Bennett WA, Burton JE (2006) Assessing nursery habitat quality for native smelts (Osmeridae) in the lowsalinity zone of the San Francisco estuary. J Fish Biol 69: 907-922

Hough AR, Naylor E (1991) Field studies on retention of the planktonic copepod Eurytemora affinis in a mixed estuary. Mar Ecol Prog Ser 76:115-122

Ide K, Takahashi K, Kuwata A, Nakamachi M, Saito H (2008) A rapid analysis of copepod feeding using FlowCAM. J Plankton Res 30:275-281

Jassby AD, Cloern JE (2000) Organic matter sources and rehabilitation of the Sacramento-San Joaquin Delta (California, USA). Aquat Conserv 10:323-352

Jassby AD, Kimmerer WJ, Monismith SG, Armor C and others (1995) Isohaline position as a habitat indicator for estuarine populations. Ecol Appl 5:272-289

Jeffries HP (1962) Salinity-space distribution of the estuarine copepod genus Eurytemora. Int Rev Gesamten Hydrobiol Hydrograph 47:291-300

*Killick R, Eckley I (2014) changepoint: an R package for changepoint analysis. J Stat Softw 58:1-19

Kimmel DG, Bradley BP (2001) Specific protein responses in the calanoid copepod Eurytemora affinis (Poppe, 1880) to salinity and temperature variation. J Exp Mar Biol Ecol 266:135-149

Kimmerer WJ (1991) Predatory influences on copepod distributions in coastal waters. In: Uye SI, Nishida S, Ho JS (eds) Proc 4th Int Conf Copepoda. Bull Plankton Soc Japan Special Vol:161-174

Kimmerer W (2004) Open water processes of the San Francisco Estuary: from physical forcing to biological responses. S Francisco Estuar Watershed Sci 2(1)

Kimmerer WJ (2006) Response of anchovies dampens effects of the invasive bivalve Corbula amurensis on the San Francisco Estuary foodweb. Mar Ecol Prog Ser 324:207-218 
Kimmerer WJ, Gould AL (2010) A Bayesian approach to estimating copepod development times from stage frequency data. Limnol Oceanogr Methods 8:118-126

Kimmerer WJ, Lougee L (2015) Bivalve grazing causes substantial mortality to an estuarine copepod population. J Exp Mar Biol Ecol 473:53-63

Kimmerer WJ, McKinnon AD (1987) Growth, mortality, and secondary production of the copepod Acartia tranteri in Westernport Bay, Australia. Limnol Oceanogr 32:14-28

Kimmerer WJ, McKinnon AD (1989) Zooplankton in a marine bay. III. Evidence for influence of vertebrate predation on distributions of two common copepods. Mar Ecol Prog Ser 53:21-35

Kimmerer WJ, Orsi JJ (1996) Causes of long-term declines in zooplankton in the San Francisco Bay estuary since 1987. In: Hollibaugh JT (ed) San Francisco Bay: the ecosystem. Pacific Division of the American Association for the Advancement of Science, San Francisco, CA, p 403-424

Kimmerer WJ, Thompson JK (2014) Phytoplankton growth balanced by clam and zooplankton grazing and net transport into the low-salinity zone of the San Francisco Estuary. Estuar Coast 37:1202-1218

Kimmerer WJ, Gartside E, Orsi JJ (1994) Predation by an introduced clam as the likely cause of substantial declines in zooplankton of San Francisco Bay. Mar Ecol Prog Ser 113:81-93

Kimmerer WJ, Burau JR, Bennett WA (1998) Tidally oriented vertical migration and position maintenance of zooplankton in a temperate estuary. Limnol Oceanogr 43: 1697-1709

Kimmerer WJ, Parker AE, Lidström UE, Carpenter EJ (2012) Short-term and interannual variability in primary production in the low-salinity zone of the San Francisco Estuary. Estuaries Coasts 35:913-929

Kimmerer WJ, Gross ES, MacWilliams ML (2014a) Tidal migration and retention of estuarine zooplankton investigated using a particle-tracking model. Limnol Oceanogr 59:901-916

Kimmerer WJ, Ignoffo TR, Slaughter AM, Gould AL (2014b) Food-limited reproduction and growth of three copepod species in the low-salinity zone of the San Francisco Estuary. J Plankton Res 36:722-735

Lakkis S (1994) Coexistence and competition within Acartia (Copepoda, Calanoida) congeners from Lebanese coastal water: niche overlap measurements. Hydrobiologia 292-293:481-490

Lampitt RS (1978) Carnivorous feeding by a small marine copepod. Limnol Oceanogr 23:1228-1231

*Lampitt RS, Gamble JC (1982) Diet and respiration of the small planktonic marine copepod Oithona nana. Mar Biol 66:185-190

Lee CE (1999) Rapid and repeated invasions of fresh water by the copepod Eurytemora affinis. Evolution 53: 1423-1434

Lee CE (2000) Global phylogeography of a cryptic copepod species complex and reproductive isolation between genetically proximate 'populations.'. Evolution 54: 2014-2027

* Lee CE, Petersen CH (2003) Effects of developmental acclimation on adult salinity tolerance in the freshwaterinvading copepod Eurytemora affinis. Physiol Biochem Zool 76:296-301

Lee CE, Posavi M, Charmantier G (2012) Rapid evolution of body fluid regulation following independent invasions into freshwater habitats. J Evol Biol 25:625-633

* Lee CE, Moss WE, Olson N, Chau KF, Chang YM, Johnson KE (2013) Feasting in fresh water: impacts of food concentration on freshwater tolerance and the evolution of food $\times$ salinity response during the expansion from saline into fresh water habitats. Evol Appl 6:673-689

Lehtiniemi M, Gorokhova E (2008) Predation of the introduced cladoceran Cercopagis pengoi on the native copepod Eurytemora affinis in the northern Baltic Sea. Mar Ecol Prog Ser 362:193-200

* Liu H, Dagg MJ, Strom S (2005) Grazing by the calanoid copepod Neocalanus cristatus on the microbial food web in the coastal Gulf of Alaska. J Plankton Res 27:647-662

Maciej Gliwicz Z (2002) On the different nature of top-down and bottom-up effects in pelagic food webs. Freshw Biol 47:2296-2312

*Marin V, Huntley ME, Frost B (1986) Measuring feeding rates of pelagic herbivores: analysis of experimental design and methods. Mar Biol 93:49-58

* Menden-Deuer S, Lessard EJ (2000) Carbon to volume relationships for dinoflagellates, diatoms, and other protist plankton. Limnol Oceanogr 45:569-579

Miller CB (1983) The zooplankton of estuaries. In: Ketchum $\mathrm{BH}$ (ed) Estuaries and enclosed seas. Elsevier, Amsterdam, p 103-149

* Modéran J, David V, Bouvais P, Richard P, Fichet D (2012) Organic matter exploitation in a highly turbid environment: planktonic food web in the Charente estuary, France. Estuar Coast Shelf Sci 98:126-137

* Nagaraj M (1992) Combined effects of temperature and salinity on the development of the copepod Eurytemora affinis. Aquaculture 103:65-71

Nobriga M (2002) Larval delta smelt diet composition and feeding incidence: environmental and ontogenetic influences. Calif Fish Game 88:149-164

Orsi JJ, Mecum WL (1986) Zooplankton distribution and abundance in the Sacramento-San Joaquin Delta in relation to certain environmental factors. Estuaries 9: 326-339

Orsi J, Ohtsuka S (1999) Introduction of the Asian copepods Acartiella sinensis, Tortanus dextrilobatus (Copepoda: Calanoida), and Limnoithona tetraspina (Copepoda: Cyclopoida) to the San Francisco Estuary, California, USA. Plankton Biol Ecol 46:128-131

Orsi JJ, Walter TC (1991) Pseudodiaptomus forbesi and P. marinus (Copepoda: Calanoida), the latest copepod immigrants to California's Sacramento-San Joaquin estuary. In: Uye SI, Nishida S, Ho JS (eds) Proc 4th Int Conf Copepoda. Bull Plankton Soc Japan Special Vol:553-562

Peterson WT (2001) Patterns in stage duration and development among marine and freshwater calanoid and cyclopoid copepods: a review of rules, physiological constraints, and evolutionary significance. Hydrobiologia 453-454:91-105

*Pope KL, Garwood JM, Welsh HH, Lawler SP (2008) Evidence of indirect impacts of introduced trout on native amphibians via facilitation of a shared predator. Biol Conserv 141:1321-1331

R Development Core Team (2013) R: a language and environment for statistical computing. R Foundation for Statistical Computing, Vienna

Rippingale R, Hodgkin E (1975) Predation effects on the distribution of a copepod. Mar Freshw Res 26:81-91

Roddie BD, Leakey RJG, Berry AJ (1984) Salinity-temperature tolerance and osmoregulation in Eurytemora affinis 
(Poppe) (Copepoda: Calanoida) in relation to its distribution in the zooplankton of the upper reaches of the Forth estuary. J Exp Mar Biol Ecol 79:191-211

Rothhaupt KO (1990) Resource competition of herbivorous zooplankton - a review of approaches and perspectives. Arch Hydrobiol 118:1-29

Runge JA (1988) Should we expect a relationship between primary production and fisheries? The role of copepod dynamics as a filter of trophic variability. Hydrobiologia 167-168:61-71

Sherr E, Sherr B (1993) Preservation and storage of samples for enumeration of heterotrophic protists. In: Kemp PF, Cole JJ, Sherr BF, Sherr EB (eds) Handbook of methods in aquatic microbial ecology. CRC Press, Boca Raton, FL, p 207-212

Shiganova TA (1998) Invasion of the Black Sea by the ctenophore Mnemiopsis leidyi and recent changes in pelagic community structure. Fish Oceanogr 7:305-310

Shurin JB, Allen EG, DeAngelis AEDL (2001) Effects of competition, predation, and dispersal on species richness at local and regional scales. Am Nat 158:624-637

* Sieracki CK, Sieracki ME, Yentsch CS (1998) An imagingin-flow system for automated analysis of marine microplankton. Mar Ecol Prog Ser 168:285-296

Simons RD, Monismith SG, Johnson LE, Winkler G, Saucier FJ (2006) Zooplankton retention in the estuarine transition zone of the St. Lawrence Estuary. Limnol Oceanogr 51:2621-2631

Slater S, Baxter R (2014) Diet, prey selection, and body condition of age-0 delta smelt, Hypomesus transpacificus, in the Upper San Francisco Estuary. S Francisco Estuar Watershed Sci 12 (3)

Slaughter AM, Ignoffo TR, Kimmerer W (2016) Predation impact of Acartiella sinensis, an introduced predatory copepod in the San Francisco Estuary, USA. Mar Ecol Prog Ser 547:47-60

Smith AP, Quin DG (1996) Patterns and causes of extinction and decline in Australian conilurine rodents. Biol Conserv 77:243-267

Soetaert K, Van Rijswijk P (1993) Spatial and temporal patterns of the zooplankton in the Westerschelde estuary. Mar Ecol Prog Ser 97:47-59
Sommer T, Armor C, Baxter R, Breuer R and others (2007) The collapse of pelagic fishes in the upper San Francisco Estuary. Fisheries 32:270-277

Stalder LC, Marcus NH (1997) Zooplankton responses to hypoxia: behavioral patterns and survival of three species of calanoid copepods. Mar Biol 127:599-607

Sullivan LJ, Kimmerer WJ (2013) Egg development times of Eurytemora affinis and Pseudodiaptomus forbesi (Copepoda, Calanoida) from the upper San Francisco Estuary with notes on methods. J Plankton Res 35:1331-1338

Telesh IV, Khlebovich VV (2010) Principal processes within the estuarine salinity gradient: a review. Mar Pollut Bull 61:149-155

* Tiselius P, Borg CMA, Hansen BW, Hansen PJ, Nielsen TG, Vismann B (2008) High reproduction, but low biomass: mortality estimates of the copepod Acartia tonsa in a hyper-eutrophic estuary. Aquat Biol 2:93-103

* Tranter DJ, Abraham S (1971) Coexistence of species of Acartiidae (Copepoda) in the Cochin Backwater, a monsoonal estuarine lagoon. Mar Biol 11:222-241

*Urabe J (1990) Stable horizontal variation in the zooplankton community structure of a reservoir maintained by predation and competition. Limnol Oceanogr 35: 1703-1717

Uye S (1986) Impact of copepod grazing on the red-tide flagellate Chattonella antiqua. Mar Biol 92:35-43

* Vanni MJ (1986) Competition in zooplankton communities: suppression of small species by Daphnia pulex. Limnol Oceanogr 31:1039-1056

* Vogt RA, Ignoffo TR, Sullivan LJ, Herndon J, Stillman JH, Kimmerer WJ (2013) Feeding capabilities and limitations in the nauplii of two pelagic estuarine copepods, Pseudodiaptomus marinus and Oithona davisae. Limnol Oceanogr 58:2145-2157

* York JK, McManus GB, Kimmerer WJ, Slaughter AM, Ignoffo TR (2014) Trophic links in the plankton in the low salinity zone of a large temperate estuary: top-down effects of introduced copepods. Estuaries Coasts 37:576-588

Yoshida T, Goka K, Ishihama F, Ishihara M, Kudo S (2007) Biological invasion as a natural experiment of the evolutionary processes: introduction of the special feature. Ecol Res 22:849-854

\section{Appendix 1}

Table A1. Parameters used to calculate the carbon cell ${ }^{-1}$ for each taxon. Count refers to how many measured cell dimensions were averaged to calculate diameter $(a, \mu \mathrm{m})$ and height $(b, \mu \mathrm{m})$ of the cells. Volumes $\left(V, \mu \mathrm{m}^{3}\right)$ were then calculated based on assignment of geometric shapes (Hillebrand et al. 1999). Calculations of cell carbon (C, pg C cell ${ }^{-1}$ ) from volume were based on conversion equations for various taxa (Menden-Deuer \& Lessard 2000). Taxa with a $\left(^{*}\right)$ were measured using an ocular micrometer on an inverted microscope at $400 \times$ magnification; all other taxa were measured with the FlowCAM at $100 \times$ magnification

\begin{tabular}{|c|c|c|c|c|c|c|c|c|c|}
\hline Taxon & Count & a & $b$ & Shape & $\begin{array}{l}\text { Volume } \\
\text { equation }\end{array}$ & $V$ & Conversion type & $\begin{array}{l}\text { Conversion } \\
\text { equation }\end{array}$ & $\mathrm{C}$ \\
\hline Centric diatoms & 30 & 29.8 & 20.3 & Cylinder & $V=(\pi / 4) a^{2} b$ & 14176 & Diatoms $>3000 \mu \mathrm{m}$ & $\mathrm{C}=0.1167 V^{0.881}$ & 530 \\
\hline Pennate diatoms & 137 & 10.2 & 28.0 & Prolate spheroid & $V=(\pi / 6) a^{2} b$ & 1525 & Diatoms & $\mathrm{C}=0.2877 \mathrm{~V}^{0.811}$ & 110 \\
\hline Diatoms $7-15 \mu \mathrm{m}$ & 185 & 6.4 & 12.8 & Cylinder & $V=(\pi / 4) a^{2} b$ & 412 & Diatoms & $\mathrm{C}=0.2877 V^{0.811}$ & 38 \\
\hline Flagellates & 252 & 13.3 & 19.2 & Prolate spheroid & $V=(\pi / 6) a^{2} b$ & 1775 & Protists $<3000 \mu \mathrm{m}$ & $\mathrm{C}=0.2612 V^{0.860}$ & 163 \\
\hline Flagellates $7-15 \mu \mathrm{m}$ & 662 & 8.3 & 11.9 & Prolate spheroid & $V=(\pi / 6) a^{2} b$ & 430 & Protists $<3000 \mu \mathrm{m}$ & $\mathrm{C}=0.2612 V^{0.860}$ & 48 \\
\hline Dinoflagellates* & 30 & 20.3 & 20.3 & Sphere & $V=(\pi / 8) a^{2} b$ & 3285 & Dinoflagellates & $\mathrm{C}=0.4436 V^{0.864}$ & 484 \\
\hline Ciliates* & 40 & 25.7 & 29.4 & Prolate spheroid & $V=(\pi / 6) a^{2} b$ & 10189 & Aloricate ciliates & $\mathrm{C}=0.2296 V^{0.984}$ & 2018 \\
\hline
\end{tabular}

